\title{
Silicon in ultrafresh groundwater: a case study of the Imandra Lake catchment, The Kola Peninsula
}

\author{
Natalia V. Guseva ${ }^{1}$, Yuliya G. Kopylova ${ }^{1}$, Daria A Vorobeva ${ }^{1, *}$, Albina A. \\ Khvashchevskaya $^{1}$, and Zinaida A. Evtyugina ${ }^{2,3}$ \\ ${ }^{1}$ National Research Tomsk Polytechnic University, 634050 Tomsk, Russia \\ ${ }^{2}$ Apatity branch of «Murmansk State Technical University», 184209 Apatity, Russia \\ ${ }^{3}$ Kola branch of Geophysical Survey of RAS, 184209 Apatity, Russia
}

\begin{abstract}
The ultrafresh groundwater (with TDS values less than $200 \mathrm{mg} / \mathrm{L}$ ) of the Imandra Lake catchment, Kola Peninsula, is from an intensive water exchange zone, where the water has a short period of contact with the rock. Therefore, the considered water is at the initial stages of the water-rock interaction. The water is saturated with respect to oxides and hydroxides of aluminium and iron. In the groundwater of the Imandra Lake catchment area, the silicon concentrations significantly exceed the concentrations of magnesium and especially potassium. Nevertheless, water is undersaturated with respect to with respect to silicon oxides. The shown enrichment of water with cations is explained by time of water-rock interaction.
\end{abstract}

\section{Introduction}

The area of Lake Imandra in the Kola Peninsula is a territory where mining and metallurgical enterprises are concentrated. The technogenic influence inevitably leads to a change in the course of hydrogeochemical processes in the catchment area [1,2]. However, the defining process in the formation of natural water of diverse composition and salinity according to modern concepts is the interaction of water with rocks [3]. At each stage of interaction in the water-rock system, a strictly defined composition of water is formed. The everlasting effects of emissions of sulfur, copper and nickel compounds have led to the degradation of forest landscapes to such an extent that forests have been completely destroyed thereby leading to the formation of man-made wastelands [4, 5]. Hence, questions regarding the chemical characteristics and the quality of water under such conditions inevitably arise $[6,7]$ and are discussed in this report.

\footnotetext{
*Corresponding author: vorobeyda18@gmail.com
} 


\section{Study area and methods}

This work is based on hydrogeochemical studies conducted in the vicinity of Lake Imandra (Kola Peninsula) in the summers of 2014 and 2016 (Fig. 1). The eastern part of the catchment area of Lake Imandra is occupied by the alkaline Khibiny Massif, and the western part of the territory is a hilly plain with a section of man-made wasteland. The geological structure is represented by basic and ultrabasic rocks, overlapped by moraine lake-glacial and fluvioglacial deposits [8].

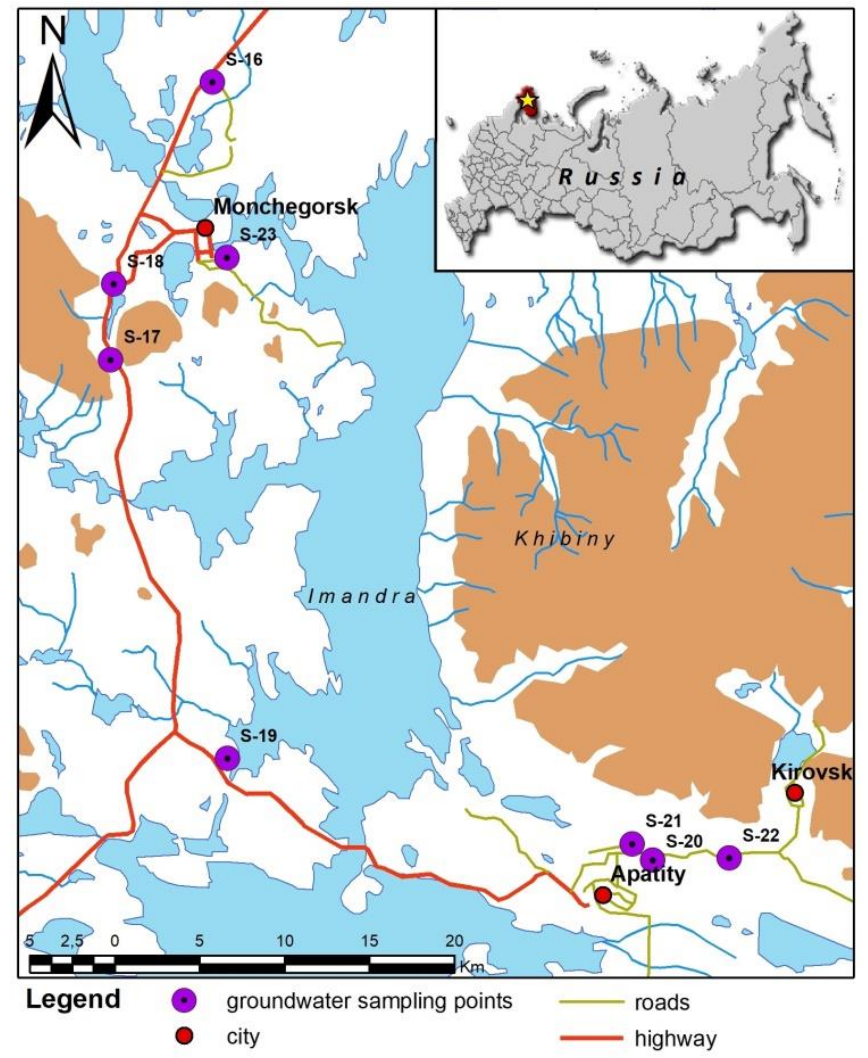

Fig. 1. Map of the studied area and sampling points.

In the Monchegorsk district, which is in the western part of the catchment of Lake Imandra, the composition of water-bearing rocks is marked by intrusive formations (granodiorites, tonalites, plagiogranites), volcanogenic formations (acidic and middle metavolcanites) of the upper (late) Archaean and intrusive formations of the lower (early) Proterozoic (norites, gabronite, dythytes, dyrophites, dyrites, dyrites, dyrites, diets, dyes, glands, and basalt porphyrites, diabases, peridotites and pyroxenites, gabbronorites) [9].

In the eastern part of the Imandra Lake catchment area, the water-bearing rocks are composed mainly of aluminosilicate formations, and the geological structure is represented by the contact of the Devonian intrusive formations (alkaline ultramafic rocks) with volcanogenic formations (basalt porphyrites and diabases) and sedimentary-interbedded andesitic basalts, porphyrites, tuffs and aleuropelitic shales of the lower (early) Proterozoic (Kelvia) [9].

Springs «Bolotnyj» (S-16), «Gornyj» (S-17), «Kislaya Guba» (S-19), «Prihibinskij» (S22), «Sportivnyj» (S-23) are present in zones, where water from atmospheric precipitation 
infiltration and from deeper crystalline basement rocks flowing upward through fractures into the ovrlying Quaternary sediments. The other springs («Dorozhnyj» S-18, «Molodezhnyj» S-20, «Poddorozhnyj» S-21) are zones of discharge of aquifers of fluvioglacial and lacustrine-glacial deposits that are recharged by precipitation [10].

The general direction of the movement of groundwater in the territory under consideration is determined by the draining effect of the surrounding seas, namely, the White and the Barents. They serve as the main basis of the entire continental run-off of this region. At the same time, due to the presence in the territory of huge lakes such as Imandra, Lovozero, Umbozero among others, that are confined to extensive depressions of tectonic origin, an underground flow of regional direction to the specified drains is formed.

The groundwater regime in the territory is determined by the climatic conditions of the Kola Peninsula, and the hydrogeological and geostructural features of the Baltic Shield. The highest level of groundwater is observed in summer (July) or autumn (October) and the lowest is usually observed at the end of winter (March-April). The change in groundwater flow in the territory coincides with a general decrease in the height of the terrain and dissection of relief in the direction from west to east and from the central mountainous part of the Kola Peninsula towards the coasts and ranges from 2.0 to $5.0 \mathrm{~L} /\left(\mathrm{s}^{*} \mathrm{~km}^{2}\right)$ and more [11].

\section{Results and discussion}

The calculated TDS values, concentrations of $\mathrm{Si}$ and $\mathrm{Si} /$ cation rations of spring waters are listed in Table 1. The chemical analysis of water was carried out in the Problem Research Laboratory of hydrogeochemistry of Tomsk Polytechnic University. To determine the macrocomponent composition of water, the following methods were used: titrimetry, photocolorimetry, flame photometry, potentiometry, turbidimetry and liquid chromatography. The microcomponent composition of water was determined by inductively coupled plasma mass spectrometry (ICP-MS).

The high groundwater flow rates and the aluminosilicate composition of water-bearing sediments determine the formation of ultrafresh water with TDS of 32-111 mg/L, pH 6-7,6 and characteristic cation ratios.

Table 1. Cation ratios in groundwater of the Lake Imandra catchment area.

\begin{tabular}{|c|c|c|c|c|c|c|c|c|}
\hline № & Spring name & TDS, $\mathrm{mg} / \mathrm{L}$ & $\mathrm{Si}, \mathrm{mg} / \mathrm{L}$ & $\mathrm{Si} / \mathrm{Ca}$ & $\mathrm{Si} / \mathrm{Mg}$ & $\mathrm{Si} / \mathrm{Na}$ & $\mathrm{Si} / \mathrm{K}$ & $\mathrm{Si} /$ cations \\
\hline S-16 & «Bolotnyj» & 61.8 & 8.37 & 1.1 & 1.9 & 2.2 & 6.2 & 0.49 \\
\hline S-17 & «Gornyj» & 30.5 & 3.70 & 0.7 & 3.5 & 2.3 & 14.1 & 0.44 \\
\hline S-18 & «Dorozhnyj» & 37.3 & 4.52 & 0.9 & 2.2 & 1.6 & 7.3 & 0.43 \\
\hline S-19 & «Kislaya Guba» & 67 & 4.97 & 0.5 & 1.8 & 1.4 & 2.4 & 0.26 \\
\hline S-20 & «Molodezhnyj» & 115 & 4.10 & 0.2 & 3.1 & 0.6 & 3.5 & 0.13 \\
\hline S-21 & «Poddorozhnyj» & 201 & 6.23 & 0.2 & 1.5 & 0.4 & 3.1 & 0.10 \\
\hline S-22 & «Prihibinskij» & 111 & 6.22 & 0.5 & 2.9 & 0.6 & 1.2 & 0.20 \\
\hline S-23 & «Sportivnyj» & 82.2 & 9.58 & 0.9 & 1.9 & 2.9 & 8.9 & 0.46 \\
\hline
\end{tabular}

The silicon content of the ultrafresh water increases with an increase in TDS from $4 \mathrm{mg} / \mathrm{L}$ in the springs «Dorozhnyj» (S-18) and «Gornyj» (S-17) that have TDS of approximately $30 \mathrm{mg} / \mathrm{L}$, while it is $8-9 \mathrm{mg} / \mathrm{L}$ in the springs «Bolotnyj» (S-16) and «Sportivnyj» (S-23), which have TDS of $62-82 \mathrm{mg} / \mathrm{L}$ in the western part of the catchment 
of Lake Imandra. In the eastern part of the Lake Imandra catchment silicon content varies from 4 to $6 \mathrm{mg} / \mathrm{L}$ while TDS ranges from 111 to $201 \mathrm{mg} / \mathrm{L}$. Here the concentrations of calcium and sodium are higher than the concentrations of silicon, while in the western part of the Imandra Lake catchment the concentrations of silicon are comparable with the concentrations of calcium and twice the concentration of sodium. In the groundwater of the Imandra Lake catchment area, the silicon concentrations significantly exceed the magnesium and especially potassium concentrations. It is useful to note that content of major anions in the studied waters is $\mathrm{HCO}_{3}{ }^{-} 11.6-101.3 \mathrm{mg} / \mathrm{L}, \mathrm{SO}_{4}{ }^{2-} 7.6-35.7 \mathrm{mg} / \mathrm{L}, \mathrm{Cl}^{-} 0.8$ $10.3 \mathrm{mg} / \mathrm{L}$.

The measured enrichment of water with major cations can be explained by the time (certain stages) of the interaction of water with minerals of the host rocks.

A comparative analysis of the composition of groundwater from the main hydrogeological provinces of the hypergenesis zone according to [12] and the studied area (Table 2) makes it possible to note the following. The silicon content in the groundwater of the Imandra Lake catchment area is comparable to the silicon content in the groundwater of the leaching provinces. However, TDS in these provinces are significantly higher than in the study area. It is noteworthy that in such lightly mineralised water the ratio of silicon to the sum of major cations reaches 0.31 , whereas for groundwater leaching a significant ratio (0.26) is observed only in the province with a tropical climate, with a total salinity of $161 \mathrm{mg} / \mathrm{L}$ and $\mathrm{Si}$ content of $9.8 \mathrm{mg} / \mathrm{L}$.

Table 2. Ratio of cations in general groundwater and that of the Lake Imandra catchment area.

\begin{tabular}{|c|c|c|c|c|c|c|}
\hline \multirow[b]{2}{*}{ Indicators } & \multicolumn{4}{|c|}{ Groundwater leaching provinces [12] } & \multirow{2}{*}{$\begin{array}{l}\text { Groundwater } \\
\text { of arid } \\
\text { climate [12] }\end{array}$} & \multirow{2}{*}{$\begin{array}{l}\text { Groundwater } \\
\text { of the Lake } \\
\text { Imandra } \\
\text { catchment area }\end{array}$} \\
\hline & $\begin{array}{l}\text { tropical } \\
\text { climate }\end{array}$ & permafrost & $\begin{array}{c}\text { mountain } \\
\text { areas }\end{array}$ & $\begin{array}{l}\text { temperate } \\
\text { climate }\end{array}$ & & \\
\hline $\mathrm{Si}, \mathrm{mg} / \mathrm{L}$ & 9.8 & 4.0 & 7.1 & 6.2 & 14.6 & 5.96 \\
\hline $\mathrm{Si} / \sum$ cations & 0.26 & 0.14 & 0.10 & 0.07 & 0.04 & 0.31 \\
\hline $\mathrm{Fe}, \mu \mathrm{g} / \mathrm{L}$ & 251 & 328 & 429 & 689 & 710 & 10 \\
\hline $\mathrm{Al}, \mu \mathrm{g} / \mathrm{L}$ & 147 & 216 & 236 & 165 & 370 & 9 \\
\hline TDS, mg/l & 161 & 121 & 270 & 337 & 1322 & 88 \\
\hline
\end{tabular}

To determine the time of water-rock interactions, an assessment of the degree of groundwater saturation with secondary mineral was made [3] for which the saturation index (SI) was calculated using the software PHREEQC (by David L. Parkhurst and C.A.J. Appelo). SI is logarithmic (IAP/Keq), where IAP is the ionic activity of the product in solution; Keq is the equilibrium constant of this reaction. The specified index allows us to estimate the degree of saturation of this solution to a particular mineral. If SI is 0 , then the solution is in equilibrium with this mineral, whereas a negative value means no saturation (the mineral dissolves) and a positive value indicates the saturation of water and the possible precipitation of the mineral.

Results show that the groundwater is in a state of saturation with oxides and hydroxides of iron and aluminium: gibbsite, hematite, goethite, diaspore and boehmite (Table 3). The highest values of SI are for hematite, from 5.09 to 12.9, in the springs of the Khibiny Massif foothills, «Molodezhnyj» (S-20), «Poddorozhnyj» (S-21) and «Prihibinskij» (S-22), in the eastern part of the Lake Imandra catchment. The water under consideration is undersaturated with respect to silicon oxides (chalcedony, quartz); these minerals dissolve, 
which explains the accumulation and high concentrations of silica in the water up to their saturation.

Table 3. Groundwater saturation indexes (SI) of the Lake Imandra catchment area with respect to secondary minerals.

\begin{tabular}{|c|c|c|c|c|}
\hline \multicolumn{2}{|c|}{ Minerals } & \multicolumn{3}{c|}{ SI } \\
\hline Name & Formula & min & ave & max \\
\hline${\text { Hydroxide } \mathrm{Al}^{3+}(\mathrm{am})}$ & $\mathrm{Al}(\mathrm{OH})_{3}$ & -2.14 & -1.70 & -1.35 \\
\hline $\mathrm{Chalcedony}^{\mathrm{SiO}}{ }_{2}$ & -0.66 & -0.48 & -0.25 \\
\hline $\mathrm{Quartz}^{3+}$ & $\mathrm{SiO}_{2}$ & -0.21 & -0.03 & 0.20 \\
\hline $\mathrm{Al}_{2} \mathrm{O}_{3}$ & -2.33 & -1.46 & -0.75 \\
\hline Oxide $\mathrm{Al}^{3+}$ & $\mathrm{Fe}(\mathrm{OH})_{3}$ & -1.36 & 1.13 & 2.54 \\
\hline Boehmitrite & $\mathrm{AlOOH}$ & 0.08 & 0.52 & 0.87 \\
\hline Gibbsite & $\mathrm{Al}(\mathrm{OH})_{3}$ & 0.37 & 0.81 & 1.16 \\
\hline Lepidocrocite & $\mathrm{FeOOH}$ & 0.46 & 2.95 & 4.36 \\
\hline Diaspore & $\mathrm{AlOOH}$ & 1.79 & 2.22 & 2.58 \\
\hline Goethite & $\mathrm{FeOOH}$ & 1.34 & 3.83 & 5.24 \\
\hline Hematite & $\mathrm{Fe} 2 \mathrm{O}_{3}$ & 5.09 & 10.06 & 12.87 \\
\hline
\end{tabular}

\section{Conclusion}

The ultrafresh groundwater (with TDS values less than $200 \mathrm{mg} / \mathrm{L}$ ) of the Imandra Lake region (Kola Peninsula) is caused by hydrogeological structure of intensive water exchange zone, where the water has a short period of the water-rock interaction. Therefore, the considered water is at the initial stages of interaction. They are saturated with oxides and hydroxides of aluminium and iron. A feature of the water under consideration is that silicon makes up a significant proportion of the sum of the major cations, i.e., from $10 \%$ to almost $50 \%$, which is true only for water of such low TDS.

This research was funded by the Russian Foundation of Basic Research (RFBR), project No 18-5580015 .

\section{References}

1. T.I. Moiseenko, Geochem. Int., 55(10), 841-860 (2017)

2. T.I. Moiseenko Water Res.,45(4), 578-588 (2018) (In Russian)

3. Geologicheskaya ehvolyuciya i samoorganizaciya sistemy voda-poroda: $v 5$ tomah. $T$. 1: Sistema voda-poroda $v$ zemnoj kore: vzaimodejstvie, kinetika, ravnovesie $i$ modelirovanie (SB RAS, 2005) (In Russian)

4. Z.A. Evtyugina, V.E. Asming Vestnik MGTU, 16(1), 73-80 (2013) (In Russian)

5. V.V. Ershov, N.V. Lukina, M.A. Orlova, N.V. Zukert Rus. J. Ecol. 47(1), 46-52 (2016)

6. V.A. Dauvalter, M.V. Dauvalter Vestnik Kolskogo naychnogo centra RAN, 3, 26-33 (2010) (In Russian)

7. T.I. Moiseenko, N.A.Gashkina Arktika: ehkologiya i ehkonomika, 4(20), 4-13 (2015) (In Russian)

8. Geologiya SSSR. Tom 27. Geologicheskoe opisanie. Murmanskaya oblast' (Gosudarstvennoe nauchno-tekhnicheskoe izdatel'stvo literatury po geologii i ohrane nedr, Moscow, 1958) (In Russian) 
9. Geologicheskaya karta Kol'skogo regiona (Apatity, 2001) (In Russian)

10. V.N. Ananev Rodniki Murmanskoy oblasti: spravochnik (Murmansk, 2010) (In Russian)

11. Resursy poverhnostnyh vod SSSR, Tom 1 Kol'skij poluostrov (Gidrometeoizdat, Leningrad, 1970. (In Russian)

12. S.L. Shvartsev Gidrogeohimiya zony gipergeneza (Nedra, Moscow, 1998) (In Russian) 